\title{
Analytical system of physiological condition of the organism (PHAUS) and a clinical example its application in practice
}

\begin{abstract}
Based on parameters of the previously developed by the author universal analytical system of physiological condition of the body (PHUAS) a new algorithm for assessing of the patient's severity was proposed. Algorithm of computer program allows identify risk groups among patients in severity general condition automatically quickly and objectively. Also, it permits to determine optimal and efficient options of prevention and treatment, avoid indepth examinations that can save both time and money. The data that were obtained could be used for the subsequent correlation with various factors that influenced on organism. These factors were such as ecology, nutrition, medications, vaccine, methods of intensive therapy, pharmacotherapy, etc. In general, the proposed algorithm allows estimating the severity of the patient's health, improving welfare of the population in terms of underfunding by means objective and rapid examination of a large number of people. The clinical example shows that the use of data analytical PHUAS system allows not only early in development identify multi-organ failure, to diagnose acute surgical pathology of abdominal cavity organs, but also to identify the root cause of its occurrence which is associated with venous thrombosis of mesenteric vessels, bowel infarction.
\end{abstract}

Keywords: algorithm, PHUAS, assess, severity, efficiency of treatment, correlation, multi-organ failure, bowel infarction
Volume 6 Issue 3 - 2018

\begin{abstract}
Andrey Belousov
Department of Anesthesiology, Transfusiology and Hematology Kharkov Medical Academy of Postgraduate Education, Ukraine
\end{abstract}

\author{
Correspondence: Laboratory of Applied Nanotechnology \\ of Belousov, Department of Anesthesiology, Intensive Care, \\ Transfusiology and Hematology Kharkov Medical Academy of \\ Postgraduate Education, Ukraine, \\ Email an.belousov2012@ukr.net
}

Received: March 23, 2018 | Published: May 02, 2018
Abbrevations: APACHE, acute physiology and chronic health evaluation; SAPS II, simplified acute physiology score; TISS, therapeutic intervention scoring system; ICU, intensive care unit

At present, the doctor's arsenal has few tens of rating scales, most of which have been used in the practice of intensive care units. Some of them have received global popularity and have been used in virtually all countries of the world (such as APACHE, SAPS, TISS), others (MPM, TOSS) have been applied more rarely., Objective assessment of the severity of the patient's condition is a necessary tool for decision-making on management of patients, solving the problems of transporting them and the optimum placement of patient care (emergency department, specialized department, ICU, etc.), comparison the outcomes of patients depending on the therapies and quality of care. The latest versions of rating scales (APACHE III, SAPS II) were build on new principles of construction - selection and weighting of variables, which based on statistical modeling techniques and the risk of death was estimated by means multiple logistic regression model. ${ }^{3}$

Today most of hospitals district and city centers have the significant deficiency of technical equipment, so using of these evaluation systems are objectively impossible. Many scoring systems are very timeconsuming and cumbersome themselves, and, therefore, they need to be updated and improved constantly. Besides, each of these systems scoring has its own specific variables for assessing of the severity of the disease. It determines not only their specifics but subjective approach in assessment of the parameters. Therefore, every physician who has used a particular evaluation system in practice often finds out inconsistency between of clinical severity of patient and result of assessment. Due this fact, the forecast of mortality is not always veridical. Another important disadvantage of the above evaluation systems is the inability to conduct a complex analysis of clinical and laboratory data. In 1990, in Leningrad, on the basis of LMT the software-Research Module for analysis of clinical and laboratory data (GEMA) was first developed. The first version of intellectual medical system was created on this basis in 1993. This software package was named OMIS. ${ }^{4}$ However, intelligent computer OMIS system couldn't be objective in general cases. The computer system wasn't able to take into account all nuances of individual clinical and laboratory data. New universal analytical evaluative system of the physiological state of the organism (PHUAS) that was created by the author was an attempt of combining the positive aspects of the above evaluative systems (Figure 1). ${ }^{5}$

Analytical PHUAS system contains different formulas that are used in medicine (for example, Astrup, Starr, De-Rittis, AlgoverBruber, Sydore, Sheych-Zade, Moore, Sumin and others). The PHUAS system allows to receive 74 integral parameters from 54 obtained analytical parameters by using of software Excel. The data obtained from 128 indicators allow the practitioner to assess objectively the overall picture of the reaction of compensatory mechanisms of physiological and pathophysiological processes and also reliably identify the basic syndrome disease; observe of the pathological process and effectiveness of the therapy. The data of evaluative system that have been obtained in dynamics after four measurements transfer automatically to the table for calculating of the coefficient of correlation, with reliability $p<0.05$. It allows to reveal the basic pathogenic links of the disease, key clinical and biochemical parameters (Figure 2). The PHUAS system calculates automatically for individual patient correction of water-electrolyte and acid-base balance, creatinine clearance, and in case of the predicted blood loss - volume of infusion solutions for hypervolemic hemodilution 
(Figure 3). Effectiveness of the program requires of basic clinical and biochemical parameters of the body that includes common clinical and biochemical analysis of venous and capillary blood, urine. Also it needs information about the water exchange in day, weight, arterial pressure, respiratory rate, heart rate and body temperature. When the patient is on artificial ventilation, it requires the mode of ventilation of lungs. Based on assessment of the PHUAS program the physician could determine objectively and reliably the main syndrome of disease, the most important biochemical parameters in individual patients and also apply these data for estimation of algorithm of the patient's severity (Figure 4).

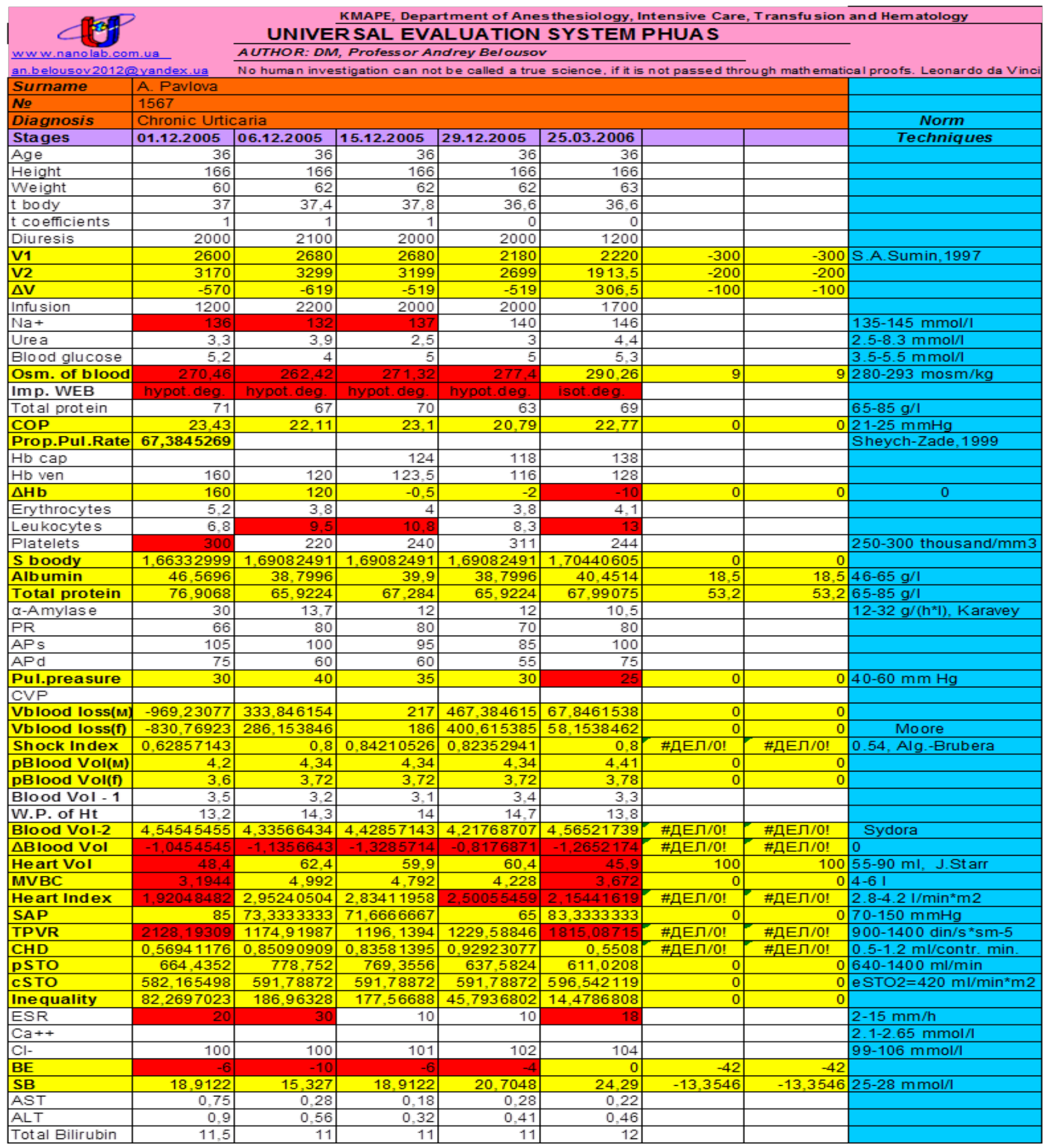

Figure I Analytical PHUAS system (fragment). 


\begin{tabular}{|c|c|c|c|c|c|c|c|c|c|c|}
\hline Creatinine & mylase & BV & BR & MVB & MVLL & $\mathrm{CaO} 2$ & $\mathrm{PaO} 2$ & Cons. 02 & $\mathrm{PaO} 2 / \mathrm{FiO} 2$ & $\frac{c a-v}{-0.11120}$ \\
\hline$-0,774597$ & $-0,2404$ & 0,258199 & 肘ЕЛ/О! & 0,258199 & 0,258199 & $-0,111208$ & $-0,111206$ & 0.914015 & $-0,111208$ & $-0,11120$ \\
\hline$-0,333333$ & 0.245618 & 0,333333 & पЕЛ/0! & 0,333333 & 0,333333 & 8234054 & $-0,324051$ & 0,813298 & $-0,324051$ & \\
\hline & 0,273389 & 0,184178 & ДЕЛ/0! & 0,184178 & 0.184178 & & $-0,187773$ & $-0,40254$ & & \\
\hline$-0,387928$ & & & \#ДЕЛ/O! & & & & & $-0,393875$ & & \\
\hline 0.225494 & 0.953573 & 0.97714 & \#ДЕЛ/0! & 0.97714 & 0.97714 & $-0,964728$ & $-0,964728$ & 0.540089 & $-0,964728$ & -0.98472 \\
\hline 0,75685 & $-0,135135$ & 0,050443 & \#ДЕЛ/0! & 0,050443 & 0,050443 & $-0,111113$ & $-0,111113$ & $-0,711773$ & $-0,111113$ & $-0,1111113$ \\
\hline$-0,19935$ & 0,228801 & $-0,142393$ & ДЕЛ/0! & $-0,142393$ & $-0,142393$ & 0,09357 & 0,09357 & 0.132598 & 0,09357 & 0,0935 \\
\hline 0,246183 & 0,410813 & $-0,492368$ & \#ДЕЛ/0! & $-0,492368$ & $-0,492386$ & 0,481884 & 0,481684 & $-0,848432$ & 0,481884 & \\
\hline 0,758597 & $-0,077291$ & $-0,006502$ & \#ДЕЛ/0! & $-0,008502$ & $-0,008502$ & $-0,059691$ & $-0,059691$ & $-0,75553$ & $-0,059691$ & $-0,05969$ \\
\hline$-0,39563$ & 0.979811 & -0.990323 & \#ДЕЛ/0! & -0.990323 & -0.990323 & 0.998708 & 0.996708 & $-0,385516$ & & \\
\hline$-0,881104$ & 0,808333 & $-0,802881$ & \#ДЕЛ $/ 0$ ! & $-0,802881$ & $-0,802861$ & 0,718184 & 0,718184 & 0,368044 & 0,718184 & 0,71818 \\
\hline$-0,455312$ & 0.98494 & $-0,98858$ & \#ДЕЛ/०! & -0.98858 & -0.98856 & & & & & \\
\hline$-0,396059$ & 0.979579 & -0.990148 & \#ДЕЛ $/ 0$ ! & $-0,990148$ & $-0,990148$ & 0,996891 & 0.998691 & 4939 & 0,998891 & \\
\hline$-0,214944$ & $-0,799055$ & 0.801154 & \#ДЕЛ, & 0.801154 & & & $-0,701898$ & & $-0,701898$ & \\
\hline$-0,374834$ & $-0,715808$ & 0.749269 & \#ДЕЛ/0! & 0.749289 & 0.749289 & $-0,852338$ & $-0,852338$ & 5837 & $-0,852338$ & $-0,85233$ \\
\hline$-0,522233$ & $-0,452425$ & 0,522233 & \#ДЕЛ/०! & 0,522233 & 0,522233 & $-0,44771$ & $-0,44771$ & 915408 & $-0,44771$ & \\
\hline 0,339373 & $-0,994773$ & 0.984481 & \#ДЕЛ/0! & 0.984481 & 0.984481 & $-0,982492$ & -0.982492 & 0,418568 & $-0,962492$ & \\
\hline 0.830554 & 0,101208 & $-0,114415$ & \#ДЕЛ/0! & $-0,11$ & $-0,114415$ & $-0,03595$ & $-0,03595$ & -0.854638 & $-0,03595$ & 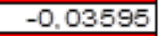 \\
\hline 0,27591 & $-0,965945$ & 0.985393 & \#ДЕЛ & 0.98 & 0.985393 & $-0,978001$ & -0.978001 & 0,497325 & $-0,978001$ & 0,978 \\
\hline$-0,060884$ & 247 & 0.915905 & \#ДЕ厂 & 0.91 & 0.915905 & $-0,880732$ & $-0,860732$ & 0,7605 & $-0,860732$ & \\
\hline$-0,074018$ & $-0,879949$ & 0,91038 & \#ДЕ & 0.9 & 0,91038 & $-0,853892$ & $-0,853892$ & 0,78891 & $-0,853892$ & $-0,853892$ \\
\hline$-0,70117$ & 0.923858 & $-0,901504$ & \#ДЕЛ, & -0.90 & -0.901504 & 0,94214 & 0.94214 & $-0,017396$ & 0.94214 & 0.94212 \\
\hline$-0,290789$ & 0.991108 & $-0,998826$ & \#ДЕЛ/ & $-0,998826$ & $-0,998826$ & 0.982748 & 0.982746 & $-0,485868$ & 0,982748 & \\
\hline 0,56528 & $-0,989923$ & 0.985271 & \#ДЕЛ/ & 0.965271 & 0.985271 & -0.991454 & -0.991454 & 0,201238 & -0.991454 & \\
\hline$-0,694133$ & $-0,398431$ & 0,446438 & \#ДЕЛ & 0,44 & 0,445438 & $-0,324847$ & $-0,324847$ & & $-0,324847$ & \\
\hline$-0,522233$ & & $-0,17$ & \#ДЕ & $-0,17$ & $-0,174078$ & 0,177799 & 0,177799 & 0,407948 & 0.177799 & 0.17779 \\
\hline \#ДЕЛ/O! & \#ДЕЛ/О! & \#ДЕЛ/0! & \#ДЕ. & \#ДЕ & \#ДЕЛ/O! & \#ДЕЛ/О! & \#ДЕЛ/O! & $\pi / 0 !$ & \#ДЕЛ/О! & \#ДЕЛ/0! \\
\hline 0.870388 & -0.587865 & 0.522233 & \#Д & 0.522233 & 0.522233 & $-0,584808$ & $-0,584808$ & 450181 & $-0,584808$ & $-0,584808$ \\
\hline 32268 & 0,046 & $-0,132$ & \#ДЕ. & $-0,13$ & $-0,13$ & 0,078607 & 0,078607 & 8322 & 0,076807 & 0,078607 \\
\hline 0,173528 & 0.81 & -0.856108 & \#ДЕЛ & -0.858108 & $-0,858108$ & 0.79359 & 0,79359 & $-0,825608$ & 0,79359 & 0,7935 \\
\hline \#ДЕЛ/О! & \#ДЕ. & \#ДЕЛ $/ 0 !$ & \#ДЕ & \#ДЕ & & \#ДЕЛ/О! & \#ДЕЛ/O! & $\pi / 0 !$ & \#ДЕЛ/ $/ 0 !$ & \#ДЕЛ/0! \\
\hline 98447 & -0.850923 & 0.832424 & \#ДE. & 0.83 & 0.832424 & -0.899554 & -0.899554 & $-0,120839$ & -0.899554 & -0.899554 \\
\hline 55312 & & & \#ДЕ. & & 356 & & & & & \\
\hline$-0,320728$ & 0,95 & -0.928941 & \#ДЕЛ & $-0,92$ & -0.9 & 0,891824 & 0,891624 & 77 & 0,891824 & 0.89162 \\
\hline \#ДЕЛ/О! & \#ДЕ & \#ДЕ & \#म & \#म & \#म & & \#ДЕЛ/0! & & \#ДЕЛ/0! & \\
\hline 3207 & $-0,3$ & 0.3 & \#Д & 0,3 & 0,3 & $-0,173$ & $-0,173942$ & 3117 & $-0,173942$ & $-0,17394$ \\
\hline 0,713748 & 47 & & \#ДЕ & & & -0.8 & & & $-0,807078$ & -0.80707 \\
\hline \multirow[t]{2}{*}{$-0,302314$} & 0.261082 & $-0,17$ & \#ДE & $-0,17$ & $-0,174843$ & 0,14 & 0,14 & 4224 & 0,140374 & 0,14037 \\
\hline & $-0,375091$ & 0.333333 & \#ДЕЛ & 0,333333 & 0,333333 & $-0,48$ & $-0,45$ & & $-0,455312$ & $-0,456$ \\
\hline \multirow[t]{10}{*}{ Amylase } & & -0.9958 & \#ПЕЛ & -0.9958 & $-0,9958$ & 3494 & 0.98494 & 98431 & 0,98494 & \\
\hline & $\mathrm{BV}$ & & \#ДЕЛ/0! & & & & & & -0.98856 & \\
\hline & & BR & \#ДЕЛ $/ 0$ ! & \#ДЕЛ/О! & \#ДЕ Л/०! & \#ДЕЛ/O! & \#ДЕЛ/0! & \#ДЕЛ/O! & \#ДЕЛ/०! & \#ДЕЛ/०! \\
\hline & & & ИVB & & & -0.98858 & $-0,98858$ & 0. & $-0,98858$ & $-0,9885$ \\
\hline & & & & & & -0.98858 & -0.98856 & 5438 & $-0,98856$ & \\
\hline & & & & & & & & $-0,324847$ & & \\
\hline & & & & & & & & $-0,324847$ & 1 & \\
\hline & & & & & & & Cons. 02 & & & \\
\hline & & & & & & & & & & \\
\hline & & & & & & & & & & \\
\hline
\end{tabular}

Figure 2 Calculation of the coefficient of correlation by using PHUAS (fragment).

The developed algorithm scoring allows determining the risk of danger of the disease, identifying the degree of clinical severity of the general condition of the patient, finding out the best financially and clinically effective way of prevention and treatment, complex assessing of the quality of the therapeutic and preventive measures. The main components of the program are systemic approach, real access to health care and social rehabilitation, regardless of gender, age and social status. Also, PHUAS provides independence, the constancy of the diagnostic and therapeutic processes, allows control the volume, quality and timeliness of delivery of health services and their compliance with medical standards. Also, the advantage of the program is not only fast and objective examination of large number of people, early identification of risk groups with severe condition, determining optimum and effective options for prevention and treatment of disease, retention of time and money for the survey, but also an ability for using the data for their correlation with external factors the environment (ecology, nutrition, addictions, vaccinations, pharmacotherapy, etc.).

As a clinical example, the difficult to diagnose in case, which was submitted to the medical consultation, was presented. The 16-years old patient was delivered to the clinic of the Kharkov Region Hospital with a diagnosis of closed head injury severe degrees of severity. From the anamnesis of the disease: head injury was hurted on the patient as a result of physical beatings. Diabetes mellitus type I was accompanying disease.

On the second day of stay in the intensive care unit against the background of massive infusion and transfusion therapies the patient's condition deteriorated dramatically due to the increasing of intoxication syndrome. Disease severity and progressing negative dynamics of clinical and laboratory parameters did not correspond to the diagnosis that was management. The clinical signs of the 
surgical diseases of the abdominal cavity was absent. In ultrasound examination of abdominal cavity organs no pathological changes were detected. Analytical PHUAS system was used for the purpose of complex assessment of clinical and biochemical parameters, objective analysis and interpretation of data. The objective data of the analytical PHUAS system that were obtained allowed to conclude that the leading syndrome of the disease was multi-organ failure, systemic inflammatory response syndrome.

\begin{tabular}{|c|c|c|c|c|c|c|c|c|}
\hline \multicolumn{9}{|c|}{ Corrective The rapy } \\
\hline K+ & 16,8 & 1,24 & 2,48 & $-12,4$ & $-11,844$ & 0 & & $3 \% \mathrm{KCl}(\mathrm{ml})$ \\
\hline $\mathrm{Ca}++$ & $20-30$ & $\mathrm{mmol} / \mathrm{l}$ & & & & & $10 \mathrm{ml} \mathrm{10 \% C}$ & $\mathrm{aCl} 2=9 \mathrm{~mm}$ ol $\mathrm{Ca}++$ \\
\hline Trisamin & -360 & -620 & -372 & -248 & 0 & 0 & 0 & $3.6 \% \mathrm{ml}$ \\
\hline $\mathrm{Na}+$ & 43,2 & 74,4 & 37,2 & 14,88 & & 0 & 0 & $10 \% \mathrm{NaCl}(\mathrm{ml})$ \\
\hline $\mathrm{NaHCO} 3$ & -120 & $-206,66667$ & -124 & $-82,666667$ & 0 & 0 & 0 & $8.4 \% \mathrm{NaHCO} 3(\mathrm{ml})$ \\
\hline $4 \% \mathrm{HCl}$ & $-64,8$ & $-111,6$ & $-66,96$ & $-44,64$ & 0 & 0 & 0 & Met. alkalosis $(\mathrm{ml})$ ! \\
\hline Creat.Clearan & 445,545455 & 460,39697 & 460,39697 & 440,37971 & $\mid 467,822727$ & \#ДЕЛ/0! & \#ДЕЛ $/ 0 !$ & $80-160 \mathrm{ml} / \mathrm{min}$ \\
\hline Am. of plas. & -48 & 148,8 & 0 & 347,2 & \begin{tabular}{|r|}
50,4 \\
\end{tabular} & 0 & 0 & $(\mathrm{ml})$ \\
\hline Am. of alb. & $-189,20448$ & 35,723904 & 2,976 & 35,723904 & $-13,650336$ & 0 & 0 & $10 \%$ Albumin $(\mathrm{ml})$ \\
\hline Corr. Infusion & 1970 & 1099 & 1199 & 699 & 213,5 & -200 & -200 & $\mathrm{ml}$ \\
\hline Vgl for K & -192 & 124 & 99,2 & 396,8 & \begin{tabular}{|r|}
388,08 \\
\end{tabular} & 0 & 0 & 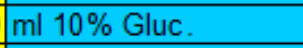 \\
\hline Hyp. deg. & $-1,5882353$ & $-2,8181818$ & $-1,3576642$ & $-0,5314286$ & 1,03561644 & \#ДЕЛ/0! & \#ДЕЛ $/ 0 !$ & (I) \\
\hline Hyper.deg & $-0,5070423$ & $-0,8732394$ & $-0,4366197$ & $-0,1746479$ & \begin{tabular}{|l|}
0,35492958 \\
\end{tabular} & 0 & 0 & $5 \%$ Glucose (I) \\
\hline Isot.deg. & 3 & 0 & 0,351417 & $-0,4275862$ & \begin{tabular}{|r|}
0,7875 \\
\end{tabular} & \#ДЕЛ/0! & \#ДЕЛ/0! & (l) \\
\hline Vinf.(olig) & 2950 & 3050 & 2950 & 2950 & 2150 & 950 & 950 & \\
\hline Pol.solution & 90 & & & & & & & $\mathrm{ml} / \mathrm{h} ! ! !$ \\
\hline \multicolumn{9}{|c|}{ Calculations for hypervolemic hemodilution } \\
\hline TVG & 1575 & $\mathrm{ml}$ & Safely until & reduced he & moglobin ar & d increases & s the MVB!!! & \\
\hline $10 \%$ Alb & 630 & $\mathrm{ml}$ & & & & & & \\
\hline Ringer & 945 & $\mathrm{ml}$ & & & & & & \\
\hline
\end{tabular}

Figure 3 Calculation of corrective therapy (fragment of PHUAS).

\begin{tabular}{|c|c|c|c|c|c|c|c|c|c|c|c|c|c|c|c|c|c|c|}
\hline \multirow[b]{2}{*}{ № } & \multirow{2}{*}{$\begin{array}{c}\text { Para-eres } \\
\text { PHUAS }\end{array}$} & \multicolumn{9}{|c|}{ Estimated.point algorithm } & \multirow{2}{*}{$\begin{array}{c}\text { Date } \\
1201.2014 \\
\end{array}$} & \multirow[b]{2}{*}{ Scores } & \multirow{2}{*}{$\left|\begin{array}{c}\text { Date } \\
26.03 .2010\end{array}\right|$} & \multirow[b]{2}{*}{ Scores } & \multirow{2}{*}{$\begin{array}{c}\text { Date } \\
\text { 21.022005 }\end{array}$} & \multirow[b]{2}{*}{ Scores } & \multirow{2}{*}{$\left|\begin{array}{c}\text { Date } \\
26.11 .2014\end{array}\right|$} & \multirow[b]{2}{*}{ Scores } \\
\hline & & 0,75 & 0,3 & 0,2 & 0,1 & 0 & 0,1 & 0,2 & 0,3 & 0,75 & & & & & & & & \\
\hline 1 & $\Delta V$ & $\angle \$ 00$ & $600-800$ & $.600-400$ & $.400-200$ & 0,2000 & $200-400$ & $400-000$ & $800-900$ & $>800$ & 204 & 0 & \begin{tabular}{|l|}
4949 \\
\end{tabular} & 0.2 & \begin{tabular}{|l|}
1740.5 \\
\end{tabular} & 0,75 & 1181,5 & 0,75 \\
\hline 2 & $1 W_{6}$ & $<15$ & 15 & 18 & 177.19 & 20.25 & 28.28 & 2930 & $>30$ & & 38 & 0.3 & 35 & 0.3 & 48 & 0.3 & 40 & 0.3 \\
\hline 3 & \begin{tabular}{|ll} 
Blodgitc \\
\end{tabular} & $<23$ & $2,42,7$ & $28.3,1$ & $3,23,4$ & $3,5.5,5$ & $58-7,5$ & $8.89,0$ & 9.14 & 314 & 8,6 & 0,1 & 4,1 & d & 3,3 & 0.1 & 5,7 & 0,1 \\
\hline 4 & $0, a b$ bbod & $<240$ & $240-285$ & $288-289$ & $270-279$ & $280-293$ & 294300 & 301315 & $318-400$ & 3400 & 298.82 & 0.1 & 283,48 & 4 & 287,36 & 0 & 291,54 & \\
\hline 5 & \begin{tabular}{|c|}
$\omega P$ \\
\end{tabular} & $<15$ & $15-18$ & $17-18,9$ & 19.20 .9 & 21.25 .9 & $28-27,9$ & 28.30 & 30.32 & $>32$ & 28.248 & 0.2 & 28,38 & 0.2 & 27,06 & 0,1 & 27,192 & 0,1 \\
\hline 8 & $\mathrm{BH} \mathrm{B}$ & <-18 & $-18-18$ & -158 & .73 & $-2+2$ & 3.7 & $8-15$ & $18-18$ & 318 & 4 & 0,1 & 5 & 0,1 & 3 & 0,1 & -10 & 0.2 \\
\hline 7 & Pistidets & $\$ 140$ & $140-159$ & $100-179$ & $180-249$ & 250.300 & $301-320$ & 321,350 & $351-400$ & 3400 & 188 & 0.1 & 1996 & 0,1 & 400 & 0.3 & 132 & 0,75 \\
\hline 8 & TPR & $\angle 900$ & & & & $900-1400$ & $1401-18000$ & $18001-2400$ & $2401-2800$ & 32000 & 215400 & 0.2 & 1781,8 & 0,1 & 1321,98 & 0 & 1708.84 & 0.1 \\
\hline 9 & Total 83 . & & & & & $8,5-20,5$ & 208.229 & 23.28 & 28.39 & $>40$ & \begin{tabular}{|l|}
11,5 \\
\end{tabular} & 0 & 28,3 & 0.2 & 10,5 & 0 & 11,4 & \\
\hline 10 & Kofins & & $<0,5$ & $0,50,54$ & $0,550,59$ & $0,80.8$ & 0.810 .9 & $0.91-1,2$ & 31,2 & & 1,44 & 0.3 & 1,38 & 0,3 & 0,48 & 0,3 & 0.92 & 0.2 \\
\hline 11 & $\mathrm{~K}_{+}$ & $\angle 3,0$ & $3,0.3 .2$ & $3,3.3 .5$ & $3,8-4,1$ & $4,25.5$ & 5,8 & $5,75,8$ & 5,9800 & 96,0 & 4,85 & 0 & 4,7 & 0 & 4,7 & 0 & 3,45 & 0.2 \\
\hline 12 & Hent Val & $\angle 38$ & $3-42$ & 42.49 & 50.54 & 55.90 & & & & & 88.814815 & 0 & 89.770541 & 0 & 110.91879 & & 95.879686 & \\
\hline 13 & taragl. & 3 & $3-4$ & $4,1-4,4$ & $4,54,9$ & $5-10$ & $11-12$ & $13-14$ & $15-18$ & $>18$ & & 0 & 6 & 0 & & 0 & & \\
\hline 14 & $\mathrm{~N}$ & & & & & 200,1 & $0,11-0,29$ & $0,30,8$ & 0,709 & 31,0 & 0,18 & 0.1 & 0,13 & 0,1 & 0,00 & 0 & 0,10 & \\
\hline 15 & Sork hodex & & $\angle 0,48$ & $0,480.5$ & $0,51-0.53$ & 0.54 & $0,550,7$ & $0,71-0.9$ & $0,91 \cdot 1,0$ & 31,0 & 0.31 & 0.3 & 0.38 & 0.3 & 0,48 & 0.3 & 0,38 & 0. \\
\hline 18 & Nosspe/sp & & & & & AO2 & $2,1-2.9$ & $3,0,5$ & $3,6,3,8$ & $>3.8$ & 1,37 & 0 & 2,44 & 0,1 & 1,07 & & 2.92 & 0.1 \\
\hline 17 & \begin{tabular}{|l|l} 
Denvir \\
\end{tabular} & & $<1008$ & $1009-1010$ & 1011-1013 & $1014-1028$ & $1023-1031$ & $1032-1034$ & 31034 & & 1015 & 0 & 1015 & 0 & 1005 & 0,3 & 1015 & \\
\hline 18 & $u / c$ & 66 & 8.7 & 89 & $10-11$ & $12 \cdot 20$ & & & & & 11,43 & 0,1 & 790 & 0.3 & 14,00 & & 10,85 & \\
\hline 19 & $\cos 0=02$ & $\$ 110$ & $110-119$ & $120-139$ & $140-179$ & 180.280 & & & & & 181,94 & 0,1 & 21286 & 0 & 259,50 & 0 & 195,11 & \\
\hline \multirow[t]{9}{*}{20} & $\mathrm{Pr} 02 / \mathrm{FO} 2$ & 4330 & $350-399$ & $400-429$ & $430-445$ & $448-455$ & $458-400$ & $481+485$ & 3485 & & 458.87] & 0.1 & 488.24 & 0.3 & 482.53 & 0.3 & 476,83 & 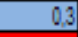 \\
\hline & & & & & & & & & \multirow{2}{*}{\multicolumn{2}{|c|}{ Dynamics: }} & & & & & & & & \\
\hline & & & & & & & & & & & Total: & 2,1 & Total: & 2,6 & Total: & 2,85 & Total: & 3,4 \\
\hline & & & & & & & & & & & \multicolumn{2}{|c|}{ IPhase } & \multicolumn{2}{|l|}{$\|$ Phase } & \multicolumn{2}{|l|}{ IIPhase } & \multicolumn{2}{|l|}{ NPhase } \\
\hline & & & & & & & & & & & & & & & & & & \\
\hline & \multicolumn{18}{|c|}{ The severity of the general condition of the patient and the risk of acute disorders of the vital functions of the body by the sum of points: } \\
\hline & & & & & & & & & |0.2.16w risk: & reventive & actiont, setis & factory 00 & ondition & & & & & \\
\hline & & & & & & & & & \multicolumn{8}{|c|}{34 -medium risk (recommended medical ther py) a date of moderate severity } & & \\
\hline & & & & & & & & & > 5 high rigk & drug ther & ipy is requires & d) a serio & ouscondifion & & & & & \\
\hline
\end{tabular}

Figure 4 Algorithm of scores of patient's severity. 
Comprehensively about it evidenced by the following calculation indicators: increase of minute volume of blood circulation ( $\mathrm{MVC}=91$ ), cardiac index $\left(\mathrm{CI}=5,76 \mathrm{l} / \mathrm{min}^{*} \mathrm{~m}^{2}\right)$, oxygen consumption $(274 \mathrm{ml} / \mathrm{min})$, index of intoxication (nuclear index $=0,7$; lymphocytes index $=3.5$ ), the decrease in total peripheral resistance $\left(\mathrm{TPR}=646 \mathrm{dyn} / \mathrm{sec}^{*} \mathrm{~cm}^{-5}\right)$, arteriovenous oxygen difference $(\mathrm{Ca}-\mathrm{v}=3 \mathrm{ml} / 100 \mathrm{ml})$, the presence of kidney and liver failure.

The deficiency of circulating blood volume (CBV) in 1 liter on the background of clinical and laboratory signs of isotonic hyperhydration (blood osmolality $=298 \mathrm{mOsm} / \mathrm{kg} ; \Delta \mathrm{V}=+900 \mathrm{ml}$ ) was revealed. Systemic analysis of indicators of the analytical PHUAS system in this case allowed not only to determine the leading syndrome of the disease, but also, based on objective data, to establish a preliminary diagnosis of the underlying pathology.

I will not limit myself to the formulation of the preliminary diagnosis, but to present a logical chain of pathophysiological arguments that led to the diagnosis: Rapid loss of a large volume of fluid in conditions of increased vascular permeability is possible only in a profusely vascularized zone. The only such area is a vascular network of the intestine. The gut is "motor" of multiple organ failure (MOF).The middle degree of intoxication does not fully explain the cause of high vascular permeability. Consequently, the only reason for the rapidly increased vascular permeability can only be venous hyperemia syndrome that cause by venous thrombosis of mesenteric vessels. The exponential increase of clinical and laboratory signs of intoxication due to a massive infusion-transfusion therapy indicate the development of acute surgical pathology of abdominal cavity organs, infarction of the bowel.Thus, the clinical example shows that the use of data analytical PHUAS system allows not only early in development identify multi-organ failure, to diagnose acute surgical pathology of abdominal cavity organs, but also to identify the root cause of its occurrence which is associated with venous thrombosis of mesenteric vessels, bowel infarction. The patient underwent emergency laparotomy. As a result of laparotomy, a final diagnosis was establishment: peritonitis, venous thrombosis of mesenteric vessels, intestinal infarction. The patient underwent surgery.

\section{Acknowledgements}

None.

\section{Conflict of interest}

There is no conflict of interest.

\section{References}

1. Zilber AP. Objectification of the patient's severity. In: Zilber AP, editor. Critical care of the medicine. Petrozavodsk: Izd Petrozavod Univ; 1995. p.131-146.

2. Bone RC. Why new definition of sepsis and organ failure are needed. Am J Med. 1993;95(4):348-350.

3. Fery Lemonniere E, Landais P, Loirat P. Evaluation of severity scoring systems in ICUs translation, conversion and definition ambiguities as a source of inter observer variability in APACHE II, SAPS and OSF. Intensive Care Med. 1995;21:356-360.

4. Genkin AA. OMIS software package as a tool for analysis of system Clinical laboratory diagnostics. Moscow Medicine. 1999;7:38-48.

5. Belousov A, Belousova E, Maloshtan V. New universal system for assessing the physiological state of the organism (PHUAS) Pain. Painkiller and Intensive Care Kiev. 2008;2(d):22-25. 